
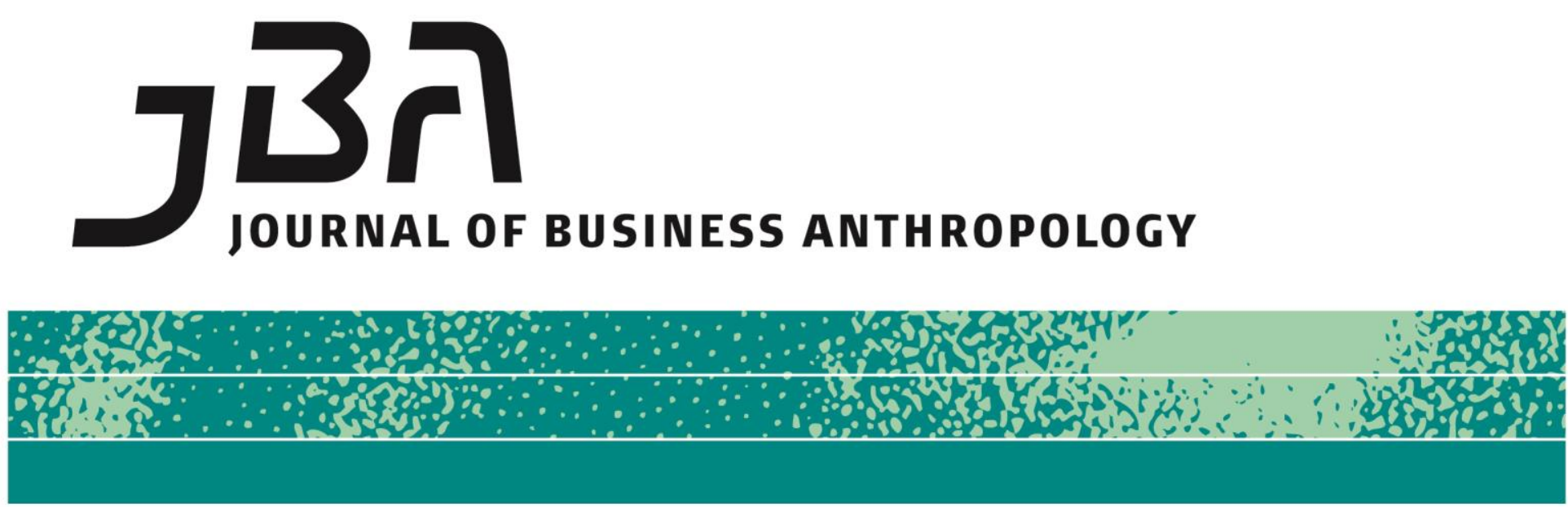

\title{
Business Ethics: a Double Bind
}

Ghislaine Gallenga, Steven Sampson and Jérôme Soldani

Issues of morality have penetrated all sub-fields of anthropology (Howell 1997; Fassin and Stoczkowski 2008; Faubion 2011). The same is true for the field of business studies, where new forms of applied ethics have emerged (Moussé 1990; Naudet 2001). These contemporary challenges pose new anthropological questions and thus offer new frameworks with which to approach ethics within the disciplines of both anthropology and business studies. In the world of business, moral concerns can take the form of a managerial strategy or personnel management tool (Both 2007; Portella et al. 2010), causing some researchers to see them mainly as an "economization" or "commodification" of ethics rather than as an "ethicization" of capitalism or of the business world (Naudet 1997; Salmon 2004 and 2007). A company's pursuit of good conduct, whatever form it takes, can be viewed cynically: as an investment intended to increase profitability, as well as a technique of deflecting external moral and political pressures (Boyer 2002; Marzano 2008). Such interpretations run the risk of becoming moral evaluations or value judgments. As anthropologists, our task is not to make such judgements, but to study how members of a business organization deal with the moral atmosphere in which they must work.

The rising focus on the ethics of business is connected to recent technological developments in production and communication, as well as to the relations of production between classes and between countries. Key trends include the transformation of companies into globalised
Page 1 of 6

JBA Special Issue 3: 1-6, Spring 2016

(C) The Author(s) 2016 ISSN 2245-4217

www.cbs.dk/jba 
production networks, automation and digitalisation of tasks, new approaches to the role of the company as a socially responsible, ethical and political actor, and the possibility of corporations to obtain positive publicity through charitable social projects or the risk of negative publicity due to social media exposing corporate scandals (Gallenga 2014:130-131).

Whereas the topics of the ethics of anthropological practice (now audited by academic research ethics committees) (Edel and Edel 1959, 1968; Bonte 1991; Caplan 2003) and business ethics (particularly in management sciences) (Anquetil 2010; Ballet 2011) have been extensively discussed, there are few anthropological studies that seek to combine both dimensions simultaneously. Notable examples of such combinations are those discussing entrepreneurship and Islam in Malaysia (Sloane 1999) and Indonesia (Rudnyckyj 2010) or, on a larger scale, the contributions on business ethics in Southeast Asia (Gallenga and Soldani 2013).

In the international public sphere, Corporate Social Responsibility (CSR) has stimulated a debate on the transition from ethics within an organisation to the ethics of the company in society, whereby certain collective work principles are promoted as expressions of the company's norms and values (Laget 2009; Capron and Quairel-Lanoizelée 2010). While there has been an increasing trend for companies to develop codes of ethics and charters of good conduct, this phenomenon is not new, having originated in the early 20 th century. Yet the trend toward making ethics more prominent is a response to the societal demand for inserting ethics into the life of the workplace and into the economic sphere of business generally (Sen 1993; Naudet 1999; Arnsperger and Van Parijs 2003). The "ethical turn" (Fassin 2014) also reflects a change in the way companies represent themselves in society, as manifested through their involvement in civic campaigns for greenwashing, fair trade, sustainable development, and so on (Salmon 2009).

As anthropologists, we have always oscillated between universal and particular forms of ethics in the societies we study, and this has led us to try and avoid the pitfalls of essentialism and normative discourse (Eberhard 2009). Contemporary research in the field of management or applied ethics considers the moral aspect of business in its normative sense: is the purpose of business "really" moral? Are certain management or business practices more morally acceptable than others? How can production be moralised? However, research seldom focuses on business ethics as an object of research in itself. These papers attempt to rectify this shortcoming by focusing explicitly on the anthropology of the business ethics imaginary.

Today, the discourse and practices of business ethics can be found everywhere. But what exactly does this concept include? How can we define it in explicitly anthropological terms? For the manager as well as 
the anthropologist, business ethics-in terms of its ideas and practices-involves dealing with opposing notions, often constructed in terms of the opposition between market efficiency versus the "costs" of ethics. As a matter of fact, an ethical approach can only grow out of a situation of double bind (Bateson 1972) comprising injunctions that are technically contradictory: being "good" according to one actor means being "bad" according to another (Kant 1997; Wittgenstein 2008; Badiou 2011). The actor-person, manager, organization-is constantly seeking to stay in line with a notion of ethics, seen as the only condition of success, and favours one injunction to the detriment of another. The result is that any given moral action deemed acceptable by one party may lead to moral disapproval by others. Ethics would thus mean reconciling the irreconcilable (Morin 2004).

Because the manager is torn between objectives of accumulating and harnessing resources within the marketplace and dealing with moral judgements of economic activity (working time increasing, using pollutants, and so on, versus employees' well-being, preservation of natural resources, and so forth), the manager both initiates and suffers from this double bind. The same can also be said of the anthropologist, for whom there is the ethical question of the thin line between the descriptive task and the critical dimension of our discipline. Ethics can be seen as the search for an optimal balance. Defining such balance inevitably creates conflicts between diverging interests. In the anthropology of business ethics, this tension is twofold: the manager is torn between two imperatives-ethics versus efficiency-while the researcher is caught up between scientific neutrality and social engagement.

This dilemma is highlighted in this collection of papers. Is "Business Ethics" a set of philosophical principles-a kind of code-or is it simply a tool in the production process? This issue is explored by Ghislaine Gallenga, who underscores the need to "anthropologize" business ethics, to see how it operates in the workplace. Following this, Arnaud Kaba describes how the owner of an Indian tea plantation, in all his patrimonial glory, can manipulate the discourse of "Fair Trade" in running his enterprise. Old fashioned patronage somehow meshes with-but also contradicts-Corporate Social Responsibility. Researching a Taiwanese baseball club, Jérôme Soldani shows how the club's official corporate values of "Health, Honor, Harmony, Honesty, Humility" are articulated as a microcosm of the company, and of society. Yet the club remains racked by continuing scandal, and the players display alternative, even resistant values. Anyone who has followed the TV drama Mad Men would be surprised to find business ethics at the core of an advertising agency. Yet in her analysis of a Paris ad agency, Léa Porée demonstrates how ethics becomes the very product of the ad firm. The firm's morality is its capital. Mad Men's Don Draper would certainly revel in Porée's article. Finally, the issue of "moral capitalism" is confronted directly in Steven 
Sampson's paper, which describes the Ethics and Compliance industry in American firms. Ethics and Compliance operates at the intersection of avoiding prosecution and acting ethically-"doing things right" versus "doing the right thing."

Despite their widely diverse settings and data, the case studies here reveal some key insights and some future tasks of an anthropology of business ethics. First, is the role of ethics as a lived practice by actors rather than a simple code to be respected, ignored or breached? The articles here show the veritable production of ethics by the actors. Ethics is thus more a tool than a code. A second insight from these case studies is the inseparability of moral and economic life: the economic activities in these organizations are intimately bound by moral projects, justifications, and objectives. This means that distinguishing a research field of "the economic" from "the moral" is not only misleading, but methodologically unproductive. The anthropological task is not to locate or distinguish the moral and ethical dimensions of business life, but to show the intermingling of business and ethics. These articles show how organizations and firms are attempting to become moral communities; in fact, establishing such moral communities seems to be one of the major tasks of management, whether it be in its more participatory form or as patrimonial. Finally, there is the research challenge of entering the often closed world of business and organizations in the search for the ethical. The research task is not to flesh out the code, nor simply to demonstrate ethics as some kind of façade. Rather, our task is to describe and understand how actors experience morality and ethics, including moral dilemmas. This indeed is the double bind described in these articles.

Exploring the double bind of business ethics in the anthropology of the workplace and business anthropology highlights the constraints that must be taken into account in the production of anthropological discourse. We hope that this special issue elucidates the role of ethical practice as an object of business anthropology and of anthropology generally.

\section{References}

Anquetil, A. et al. 2010. Éthique de l'entreprise. Réalité ou illusion? Paris: L'Harmattan.

Arnsperger, C. and P. Van Parijs. 2003. Éthique économique et sociale. Paris: La Découverte.

Badiou, A. 2011 [2003]. L'éthique. Essai sur la conscience du mal. Caen: Nous.

Ballet, J. et al. 2011. L'entreprise et l'éthique. Paris: Seuil.

Bateson, G. 1972. Steps to an ecology of mind. Chicago: University of 
Chicago Press.

Bonte, P. 1991. Questions d'éthique en anthropologie. Sociétés contemporaines 7: 73-85.

Both, A. 2007. Les managers et leurs discours. Anthropologie de la rhétorique managériale. Pessac: Presses Universitaires de Bordeaux.

Boyer, A. 2002. L'impossible éthique des entreprises. Réflexions sur une utopie moderne. Paris: Éditions d'Organisation.

Caplan, P. ed. 2003. The ethics of anthropology: debates and dilemmas. London and New York: Routledge.

Capron, M. and F. Qarirel-Lanoizelée, 2010. La responsabilité sociale d'entreprise. Paris: La Découverte.

Eberhard, C. 2009. Au-delà de l'universalisme et du relativisme : l'horizon d'un pluralisme responsable. Anthropologie et Sociétés 33(3): 79-100.

Edel, M. and A. Edel. 1959. Anthropology and ethics. Springfield, IL: Thomas.

Edel, M. and A. Edel. 1968. Anthropology and ethics: the quest for moral understanding. Cleveland: Case Western Reserve University Press.

Fassin, D. 2014. The ethical turn in anthropology: promises and uncertainties. Hau: Journal of Ethnographic Theory 4 (1): 429-435.

Fassin, D. and W. Stoczkowski. 2008. Should anthropology be moral? A debate. Anthropological Theory 8: 331-332.

Faubion, J. 2011. An anthropology of ethics. Cambridge: Cambridge University Press.

Gallenga, G. 2014. Penser au miroir de l'éthique (interview by Émir Mahieddin). Journal des anthropologues 136-137: 123-136.

Gallenga, G. and J. Soldani. 2013. Lectures anthropologiques de l'éthique entrepreneuriale. Moussons 21, http://moussons.revues.org/2071, accessed March 26, 2016.

Howell, S. (ed.) 1997. The Ethnography of moralities. Londres and New York: Routledge.

Kant, E. 1997 [1785]. Leçons d'éthique. Paris: Le Livre de poche.

Laget, P. 2009. Responsibilité d'entreprise et éthique sont-elles solubles dans la mondialisation ? Paris: Éditions de l'Aube.

Marzano, M. 2008. L'éthique appliquée. Paris: PUF, Que sais-je ?.

Morin, E. 2004. La méthode 6. Éthique. Paris: Seuil.

Moussé, J. 1990. Éthique et entreprises. Paris: Vuibert.

Naudet, J.-Y. 1997. Éthique des affaires. De l'éthique de l'entrepreneur au droit des affaires. Actes du colloque d'Aix-en-Provence, 4 et 5 juillet 1996. Aix-en-Provence: Librairie de l'Université. 
Naudet, J.-Y. 1999. Morale économique. Des fondements religieux à l'éthique en entreprise. Actes du colloque d'Aix-en-Provence, 2 et 3 juillet 1998. Aix-en-Provence: Librairie de l'Université.

Naudet, J.-Y. 2001. Éthique en entreprise. Actes du colloque d'Aix-enProvence, 6 et 7 juillet 2000. Aix-en-Provence: Librairie de l’Université.

Portella, A. et al. 2010. L'éthique en entreprise. Manuel à l'usage des responsables $R H$ et des managers. Paris: Studyrama.

Rudnyckyj, D. 2010. Spiritual economies: Islam, globalization, and the afterlife of development. Ithaca: Cornell University Press.

Salmon, A. 2004. L'offre éthique des entreprises. Cahiers internationaux de sociologie 1(116): 77-96.

Salmon, A. 2007. La tentation éthique du capitalisme. Paris: La Découverte. Salmon, A. 2009. Moraliser le capitalisme ? Paris: CNRS éditions.

Sen, A. 1989. On ethics and economics. Oxford: Wiley-Blackwell.

Sloane, P. 1999. Islam, modernity and entrepreneurship among the Malays. Londres: Palgrave Macmillan.

Thévenet, M. 1994. La culture d'entreprise. Paris: PUF.

Wittgenstein, L. 2008 [1967]. Conférence sur l'éthique. Paris: Folio. 